\title{
Multiple Forms of Pancreatic Polypeptide-Related Compounds in the Lamprey CNS: Partial Characterization and Immunohistochemical Localization in the Brain Stem and Spinal Cord
}

\author{
Lennart Brodin, ${ }^{1}$ Allen Rawitch, ${ }^{4}$ Timothy Taylor, ${ }^{4}$ Yoshihiro Ohta, ${ }^{1}$ Helena Ring, ${ }^{2}$ Tomas Hökfelt, ${ }^{3}$ \\ Sten Grillner, ${ }^{1}$ and Lars Terenius ${ }^{5}$ \\ 'Nobel Institute for Neurophysiology, ${ }^{2}$ Department of Medical Chemistry II, and ${ }^{3}$ Department of Histology and \\ Neurobiology, Karolinska Institutet, S-104 01 Stockholm, Sweden, ${ }^{4}$ Department of Biochemistry and Molecular Biology, \\ University of Kansas Medical Center, Kansas City, Kansas 66103, and ${ }^{5}$ Department of Pharmacology, University of \\ Uppsala, S-750 00 Uppsala, Sweden
}

\begin{abstract}
Although neuropeptide $Y$ (NPY) is established as a transmitter in many regions of the nervous system, the role of other peptldes of the pancreatic polypeptide (PP) family in the CNS is obscure. This study provides evidence that PPlike peptides in the "primitive" CNS of a cyclostome are composed of different molecular forms, which are stored in separate neuronal populations with apparently different functions. PP-like material was detected in extracts of brain and spinal cord from Lampetra fluviatilis by radioimmunoassay (RIA) using an antiserum to the C-terminal hexapeptide of mammalian PP. The PP-immunoreactive material consisted of several molecular forms, as shown by its complex elution profile on high-performance liquid chromatography (HPLC). The cellular distribution of PP-like immunoreactivity was studied with indirect immunofluorescence histochemistry using antisera toward porcine peptide $Y Y$ (PYY), porcine neuropeptide Y (NPY), and bovine (BPP), rat (RPP), and avian (APP) pancreatic polypeptide. Adjacent sections from the brain stem and spinal cord of $L$. fluviatilis and Ichthyomyzon unicuspis, incubated with the different antisera, displayed 2 main patterns of PP immunoreactivity. The PYY and RPP antisera labeled groups of neurons and fibers in the rhombencephalic and mesencephalic reticular formation. One of the PYY/RPP-ir cell groups, located in the anterior rhombencephalic reticular nucleus, had a projection to the dorsolateral spinal cord. Fibers of this reticulospinal system were in close apposition to dendrites of intracellularly stained spinal motoneurons and sensory relay interneurons, indicating that they may receive PPergic input. In contrast, antisera to NPY and APP labeled local neuron systems in the spinal dorsal horn, in the lateral parts of the brain stem, including the rhombencephalic alar plate, and in the retina. The BPP antiserum recognized the NPY/APP as well as the PYY/RPP immunoreactive neuron systems, further supporting that they both contain PP-like peptides.
\end{abstract}

Received Jan. 17, 1989; revised Mar. 14, 1989; accepted Mar. 20, 1989.

This study was supported by grants from the Swedish Medical Research Council (grants no 2887 and 3026) and Karolinska Institutets Fonder. For skillful technical assistance we are indebted to Monica Bredmyr, Pernilla Grillner, and Siv Nilsson. We thank Bjarne Ragnarsson and coworkers, Älvkarleby, and Sigvard Uppman, Ljusne, for the generous supply of lampreys.

Correspondence should be addressed to Lennart Brodin, Nobel Institute for Neurophysiology, Karolinska Institutet, Box 60400, S-10401 Stockholm, Sweden.

Copyright $\odot 1989$ Society for Neuroscience $0270-6474 / 89 / 103428-15 \$ 02.00 / 0$
Pancreatic polypeptide (PP), peptide YY (PYY), and neuropeptide Y (NPY) together form the family of pancreatic polypeptides. These peptides were isolated originally from the pancreas (PP), gut (PYY), and brain (NPY), respectively (Kimmel et al., 1968, 1975; Lin and Chance, 1974; Tatemoto, 1982a, b). NPY is abundant both in the central and in the peripheral nervous system, and it is believed to act as a neurotransmitter-neuromodulator (Tatemoto, 1982b, 1989; Allen et al., 1983; Everitt et al., 1984; Lundberg et al., 1984; Chronwall et al., 1985; DiMaggio et al., 1985; DeQuidt and Emson, 1986a, b). At first, it was believed that all PP-like material in the CNS consisted of NPY, but subscquent studies have indicated that other PPrelated peptides may be present. In the rat CNS, immunoreactivity to PYY has been detected with both immunohistochemistry and radioimmunoassay (RIA; Lundberg et al., 1984; Broomé et al., 1985; Ekman et al., 1986; see also Inui et al., 1985; DiMaggio et al., 1985). Although this immunoreactivity has properties distinct from NPY, it is uncertain whether it represents true PYY or is due to cross-reactivity with a yet unidentified PP (Tatemoto, 1989).

Biochemical characterization of PPs in the vertebrate CNS has so far been confined to mammalian species, but immunochemical and immunohistochemical investigations in lower vertebrates have suggested that neuronal PPs are widely distributed in phylogeny (Böttcher et al., 1985; Danger et al., 1985; VanDongen et al., 1985; Negishi et al., 1986; Perroteau et al., 1988; Vallarino et al., 1988; see also Sundler et al., 1977; Duve et al., 1982). The agnathan vertebrates, i.e., lampreys and hagfishes, are of particular interest in comparative neurobiology, since they deviated early from the main vertebrate line, and their nervous system is considered, by many investigators, to have kept many features from the CNS of primitive vertebrates (see, e.g., Nieuwenhuys, 1977; Grillner et al., 1987). In the lampreys Lampetra fluviatilis, Ichtyomyzon unicuspis, and Lampetra japonica, a presumed PP-like peptide has been detected in spinal and retinal nerve cells by using antiserum to porcine NPY (VanDongen et al., 1985; Negishi et al., 1986). We have now extended the analysis of PP-like neuropeptides in lamprey by RIA and high-performance liquid chromatography (HPLC) analysis of brain and spinal cord extracts and by immunohistochemical localization of PP immunoreactivity in the brain stem and spinal cord with different types of PP antisera. A preliminary report has been given (Brodin et al., 1988c). 


\section{Materials and Methods}

Animals. Adult river lampreys (L. fluviatilis) were obtained from Ljusne and Älvkarleby, Sweden, and adult silver lampreys (I. unicuspis) were obtained from Guttenberg, Iowa. The biochemical analysis was carried out on river lampreys, and both species were used for immunohistochemistry. The animals were kept in aerated aquaria with a temperature of $3-5^{\circ} \mathrm{C}$ and anesthetized with tricaine methanesulphonate (MS-222) before dissection.

Tissue extraction. Pooled brains ( $1.62 \mathrm{gm})$ and spinal cords (7.57 gm) from 25 animals were minced and transferred to two $50-\mathrm{ml}$ centrifuge tubes, and $0.582 \mathrm{ml} / \mathrm{gm}$ tissue of a $95 \%$ ethanol: $\mathrm{H}_{2} \mathrm{SO}_{4}$ : water solution $(825: 20.6: 155 \mathrm{vol} / \mathrm{vol})$ was added to each tube, followed by $3.38 \mathrm{ml} /$ $\mathrm{gm}$ tissue of $95 \%$ ethanol : water (805:195 vol/vol) (Pettinga, 1958). The tissue was homogenized, and an extra $10 \mathrm{ml}$ of $80 \%$ ethanol, used to wash the macerating rod, was included. The homogenate was stirred for $1 \mathrm{hr}\left(20^{\circ} \mathrm{C}\right)$ and centrifuged at $16,000 \times g$ for $5 \mathrm{~min}$. The supernatants were retained, and the resulting pellets were combined and homogenized in $20 \mathrm{ml}$ of $95 \%$ ethanol: $\mathrm{H}_{2} \mathrm{SO}_{4}$ :water $(667: 2.5: 331 \mathrm{vol} / \mathrm{vol})$. This second homogenate was stirred for $90 \mathrm{~min}$ and centrifuged as above, and the supernatant was combined with the first extract supernatant, giving a total extract volume of approximately $75 \mathrm{ml}$. The $\mathrm{pH}$ was adjusted to 3.25 by adding concentrated ammonia, and an aliquot was taken for RIA. Ethanol $(95 \%, 150 \mathrm{ml})$ was then added with stirring, followed by $300 \mathrm{ml}$ of dry ethyl ether. The acid-ethanol ether extract was kept at $5^{\circ} \mathrm{C}$ for $48 \mathrm{hr}$, and the fine white precipitate was collected on Whatman No. 1 filter paper. The flask was washed twice with $10 \mathrm{ml}$ of $95 \%$ ethanol: acetone $(50: 50)$, and the washings were poured through the collected precipitate, which was air dried $(30 \mathrm{~min})$. All items used were then washed with $1 \mathrm{M}$ acetic acid $(8 \mathrm{ml})$ that was added to the precipitate, which was vortexed and allowed to stand for $2 \mathrm{hr}$, followed by centrifugation. The supernatant was retained, and the precipitate was extracted 3 additional times with $2-3 \mathrm{ml}$ of $1 \mathrm{M}$ acetic acid. All extracts were combined, shell frozen, and then lyophilized. A sample of the resulting dry extract was taken for RIA, and the bulk of the material was stored at $-20^{\circ} \mathrm{C}$.

Gel filtration. The lyophilized crude extract was redissolved in $5 \mathrm{ml}$ of $1 \mathrm{M}$ acetic acid and applied to a column of Sephadex G50 superfine $(1.5 \times 51 \mathrm{~cm})$ equilibrated with $1 \mathrm{M}$ acetic acid. The column was standardized using BSA, egg white lysozyme, insulin, and $\mathrm{NaCl}$ before application of the neurotissue extract. The column was eluted at a flow rate of approximately $10 \mathrm{ml} / \mathrm{hr}$, and $2-\mathrm{ml}$ fractions were collected. The region of the elution profile corresponding to molecular weights between approximately 1500 and 15,000 was pooled, and following the removal of an aliquot for RIA, the pooled fraction was lyophilized and stored at $-20^{\circ} \mathrm{C}$.

HPLC fractionation. The lyophilized PP/NPY containing fraction from the G50 chromatography was taken up in $400 \mu \mathrm{l}$ of $0.1 \%$ trifluoroacetic acid:water and applied to a Vydac $\mathrm{C} 18$ reverse phase column on a Beckman Model 342 HPLC system. The initial column conditions were $0.1 \%$ trifluoroacetic acid in water (buffer $\mathrm{A}$ ), and the system was eluted at a flow rate of $1.0 \mathrm{ml} / \mathrm{min}$. A linear gradient of increasing acetonitrile containing $0.1 \%$ trifluoroacetic acid (buffer B) was developed from 0 to $100 \%$ over 100 min. Effluent was monitored at both 220 and $280 \mathrm{~nm}$, and $1-\mathrm{ml}$ fractions were collected for RIA and further characterization (see Fig. 2).

$R I A$. RIAs were carried out as described by Pollock and Kimmel (1981), using a rabbit antiserum directed to the C-terminal hexapeptide of bovine pancreatic polypeptide (BPP) (Pollock et al., 1987). Results were calculated in terms of a standard displacement curve using radioiodinated BPP and are, therefore, calculated as equivalents of BPP.

Surgical procedures. To test for degeneration of descending spinal fibers, 4 animals were subjected to hemisection of the rostral spinal cord at the level of segment $8-10$. The rostral spinal cord was exposed via a dorsal incision under visual inspection with a dissection microscope, one hemisegment was carefully removed, and the wound was sutured. The operated animals were left to survive for a period of 3-3.5 months (c.. Brodin et al., 1988a). The extent of the lesion was cxamined in transversal sections from the lesioned area (see Fig. $3 B$ ).

Descending projections of brain-stem neurons were studied by injecting the tracer fluorescent dextranamine (FDA, 25\% in water; Gimlich and Brown, 1985; Glover et al., 1986) into the rostral spinal cord (segment 10-12). The exposed spinal cord was penetrated at 2-3 points on each side with a glass micropipette filled with FDA solution, and a small droplet of dye was injected by air pressure delivered from a pneu- matic system (NeuroPhore, Medical Systems Corp., New York). Care was taken to avoid dye leakage from the spinal cord. After 6 weeks of survival, the animals were anesthetized, the spinal cord was transected at segment $4-5$, the dorsal cranium was removed, and the exposed brains were stored in physiological solution at $5-8^{\circ} \mathrm{C}$ for $12-24 \mathrm{hr}$ to enhance the immunoreactivity of descending peptide-containing neurons (cf. Brodin el al., 1988a).

Intracellular dye injections. To identify close appositions between immunostained fibers and spinal neurons, suggestive of synapses, intracellular injections of Lucifer yellow (LY) were made in the in vitro preparation of the isolated lamprey spinal cord (see Grillner et al., 1987; Ohta et al., 1988). Ten- to 20 -segment-long pieces of spinal cord-notochord were mounted in a chamber with physiological solution at $7-$ $9^{\circ} \mathrm{C}$. Different cell types were impaled with $\mathrm{LY}$-filled ( $5 \%$ in $\left.0.3 \mathrm{M} \mathrm{LiCl}\right)$ micropipettes (resistance $50-70 \mathrm{~m} \Omega$ ), and the dye was injected by air pressure. Motoneurons were identified by recording of the axonal spike in an adjacent ventral root. Giant interneurons, lateral interneurons, and dorsal cells were identified by their typical morphology (see Rovainen 1979). The preparations were processed for immunohistochemistry as described below.

Immunohistochemistry. After dissection, the brains, spinal cords, and retinas were immersed for $1-2 \mathrm{hr}$ in a $4^{\circ} \mathrm{C}$ solution of paraformaldehyde $(40 \mathrm{~g} / \mathrm{liter})$ in $0.16 \mathrm{M}$ phosphate buffer, $\mathrm{pH} 6.9$, with picric acid $(2 \mathrm{~g} /$ liter) (Zamboni and DeMartino, 1967). Thereafter, the tissues were rinsed in $0.1 \mathrm{M}$ phosphate buffer, $\mathrm{pH} 7.2$, with $15 \%$ sucrose, $0.01 \% \mathrm{Na}$ azide, and $0.02 \%$ bacitracin for at least $12 \mathrm{hr}$. Transversal or horizontal sections of $14 \mu \mathrm{m}$ thickness were cryostat sectioned and incubated for $18-24 \mathrm{hr}\left(4^{\circ} \mathrm{C}\right)$ in antisera raised in rabbits against porcine PYY $(69 \mathrm{~B})$, porcine NPY (102B, C), bovine PP (BPP) (417), avian PP (K01), and rat PP (see Lundberg et al., 1982, 1984) at dilutions of 1:200-1:400. The NPY antiserum recognizes the $\mathrm{N}$-terminal sequence of the peptide (Lundberg et al., 1984). After rinses in PBS, the sections were incubated in antirabbit antibodies coupled to fluorescein isothiocyanate (FITC) or tetramethylrhodamine isothiocyanate (TRITC) (Boehringer Mannheim Scandinavia, Stockholm, Sweden; Amersham, Amersham, England). After additional rinses in PBS, the sections were mounted in a glycerolPBS mixture (1:3) containing $0.2 \% P$-phenylenediamine (Johnson and De C. Nogueira Araujo, 1981) and examined in a Zeiss or Nikon fluorescence microscope. Antibodies coupled to TRITC were always used in the retrograde tracing (FDA) and intracellular staining (LY) experiments. To visualize the 2 types of fluorescence in the same section, the fluorescence filters were switched between settings for TRITC and FITC (see Brodin et al., 1988a; Ohta et al., 1988). An LY-stained structure was considered to be in close apposition with a PYY-immunoreactive (-ir) element when the two were in apparent contact in the same focal plane and no intervening distance could be observed at $400 \times$ magnification. The staining specificity was tested by incubating adjacent sections with antisera that had been absorbed with the appropriate peptide for $6 \mathrm{hr}$ at a concentration of $10 \mu \mathrm{g}$ peptide/ $\mathrm{ml}$ of diluted antiserum (see Results). Porcine NPY was kindly donated by Prof. V. Mutt, Stockholm, Sweden, and porcine PYY was purchased from Peninsula (Belmont, CA). The anatomical nomenclature of Nieuwenhuys (1977) and Schober (1964) has been used, and the spinal cord has been subdivided into a central "grey" cell column, a dorsal horn, and lateral, ventromedial, and dorsal fiber columns (cf. Brodin et al., 1988a).

\section{Results}

\section{$P P$-like immunoreactivity in extracts of lamprey CNS}

The crude extract of pooled brains and spinal cords ( $L$. fluviatilis) contained $30 \mathrm{pmol}(121 \mathrm{ng}$ ) immunoreactive peptide expressed as equivalents of BPP. Figure $1 A$ shows the elution profile of the crude extract on Sephadex G-50 chromatography. Broad pools were taken and tested for PP reactivity. The only significant immunoreactivity was found in the region corresponding to molecular weights between 1500 and 15,000. Displacement curves for the crude extract and for G-50 pooling are shown in Figure $1, B$ and $C$, respectively. The estimated yield of cross-reacting material from the $\mathrm{G}-50$ column (assuming full cross-reactivity) was $12.4 \mathrm{pmol}(50 \mathrm{ng})$. This material was subject to reverse phase HPLC, and the immunorcactivity was recovered in 3 main components with retention times between 

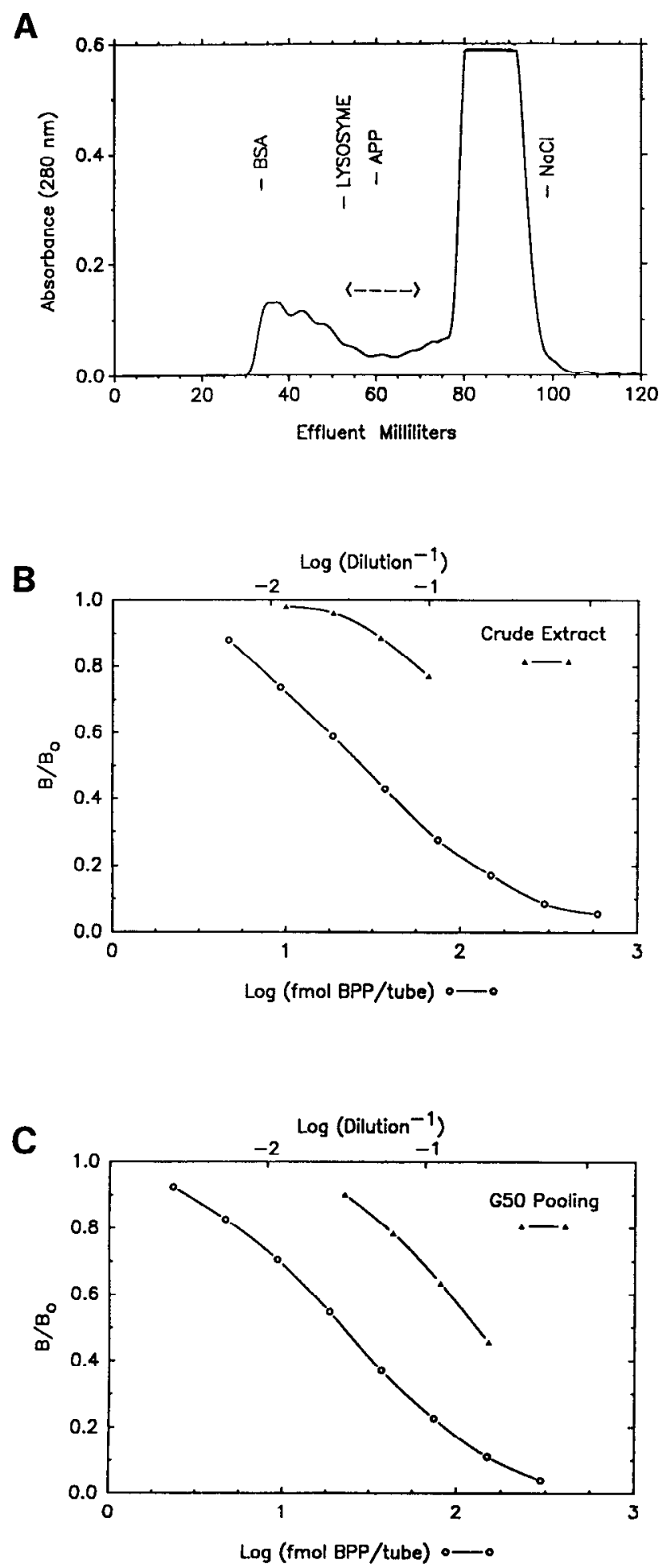

Figure 1. PP-immunoreactivity in extracts of lamprey CNS (Lampetra fluviatilis). $A$, Sephadex G-50 gel filtration of material precipitated from crude CNS extract by ether. Positions of the standards BSA, lysosyme, $\mathrm{APP}$, and $\mathrm{NaCl}$ are indicated. Hatched line indicates the fraction pooled for further studies. This fraction contained virtually all of the recovered PP-related immunoreactivity. $B, C, \mathrm{RIA}$ for PP-like antigens using a polyclonal antiserum against the C-terminal hexapeptide sequence of mammalian PP. The inhibition curves given by dilutions of the crude extract $(B$, triangles) and the pooled $\mathrm{G}-50$ fraction $(C$, triangles) are compared with those obtained with pure BPP (circles).
36 and $50 \mathrm{~min}$ (Fig. 2). These components were probably still complex, but a further separation was not attempted because of the small amounts of peptide. It is clear, however, that the PP-ir material present in the lamprey CNS is composed of several molecular forms.

\section{Immunohistochemical distribution of PP immunoreactivity in the spinal cord}

The distribution of PP immunoreactivity was similar in $L$. fluviatilis and 1 . unicuspis, and both species will be referred to as "lamprey" in the text. The species shown in the illustrations are specified in the legends.

$P Y Y$-antiserum. Antiserum raised against porcine PYY labeled fibers throughout the length of the spinal cord (Figs. 3, $4 A$ ), but no PYY-ir cell bodies were detected. The PYY-ir fibers ran longitudinally in the dorsal part of the lateral column and had frequent boutonlike swellings (Fig. 3D). As shown in Figure $3 A$, a hemisection of the rostral spinal cord (cf. Fig. $3 B$ ) resulted in a loss of the PYY-ir fibers in the lateral column of the lesioned side, suggesting a supraspinal origin (see below). In addition, a few animals displayed some weakly stained fibers in the ventromedial column. These latter PYY-ir fibers could remain below a spinal lesion (Fig. $3 A$ ), and thus they appeared to belong to a different fiber population.

To screen for possible target neurons of the descending PYYir fibers, different cell types were stained intracellularly with LY and subsequently surveyed for close appositions with PYY-ir fibers in the lateral column (14- $\mu \mathrm{m}$ thick sections; see Fig. 3, $D-F$, and Ohta et al., 1988). The motoneurons examined $(n=$ 9) had 6-14 (10 \pm 3 , mean \pm SD) close appositions between their lateral dendrites and PYY-ir fibers. Two giant interneurons (Fig. 3, $D-F$; sensory relay interneurons) showed 5 and 6 close appositions, respectively, and a single lateral interneuron had 3 close contacts. None of the 11 dorsal cells (intraspinal primary sensory neurons) examined had close appositions with PYY-ir fibers. The PYY staining was abolished after preabsorption of the antiserum with porcine PYY.

NPY antiserum. Antiserum directed to the $\mathrm{N}$-terminal region of porcine NPY labeled numerous fibers in the dorsal horn, with some fibers extending into the lateral and dorsal columns (Fig. $5, A, B, D ; \mathrm{cf}$. VanDongen et al., 1985). NPY-ir cell bodies were observed lateral to the central canal throughout the length of the spinal cord (Fig. 5B). A hemisection of the rostral spinal cord had no effect on the dorsal horn fibers (Fig. 5A), which thus may originate from segmental or caudal NPY-ir cell bodies. In some experiments, the NPY antiserum also stained fibers in the lateral column. These fibers were partly reduced below a chronic lesion (Fig. 5A). Because of their variable labeling, it could not be determined whether or not these fibers overlapped with the descending PYY-ir fibers described previously. The NPY immunofluorescence was abolished after preabsorption of the antiserum with porcine NPY.

$B P P$ antiserum. BPP-ir fibers were present in the lateral column with a distribution similar to that of PYY-ir fibers (see Figs. $4, A, B ; 3 C ; 5 E$ ). In addition, BPP-ir fibers were observed in the dorsal horn and in the lateral and ventromedial columns. The dorsal horn labeling showed a partial overlap with the fibers stained by the NPY antiserum (cf. Fig. 5, $D$ and $E$ ). A rostral spinal lesion caused a loss of the BPP-ir fibers in the lateral column that overlapped with PYY-ir fibers, whereas the BPPir fibers in other regions were unaffected. Unlike the other PP 


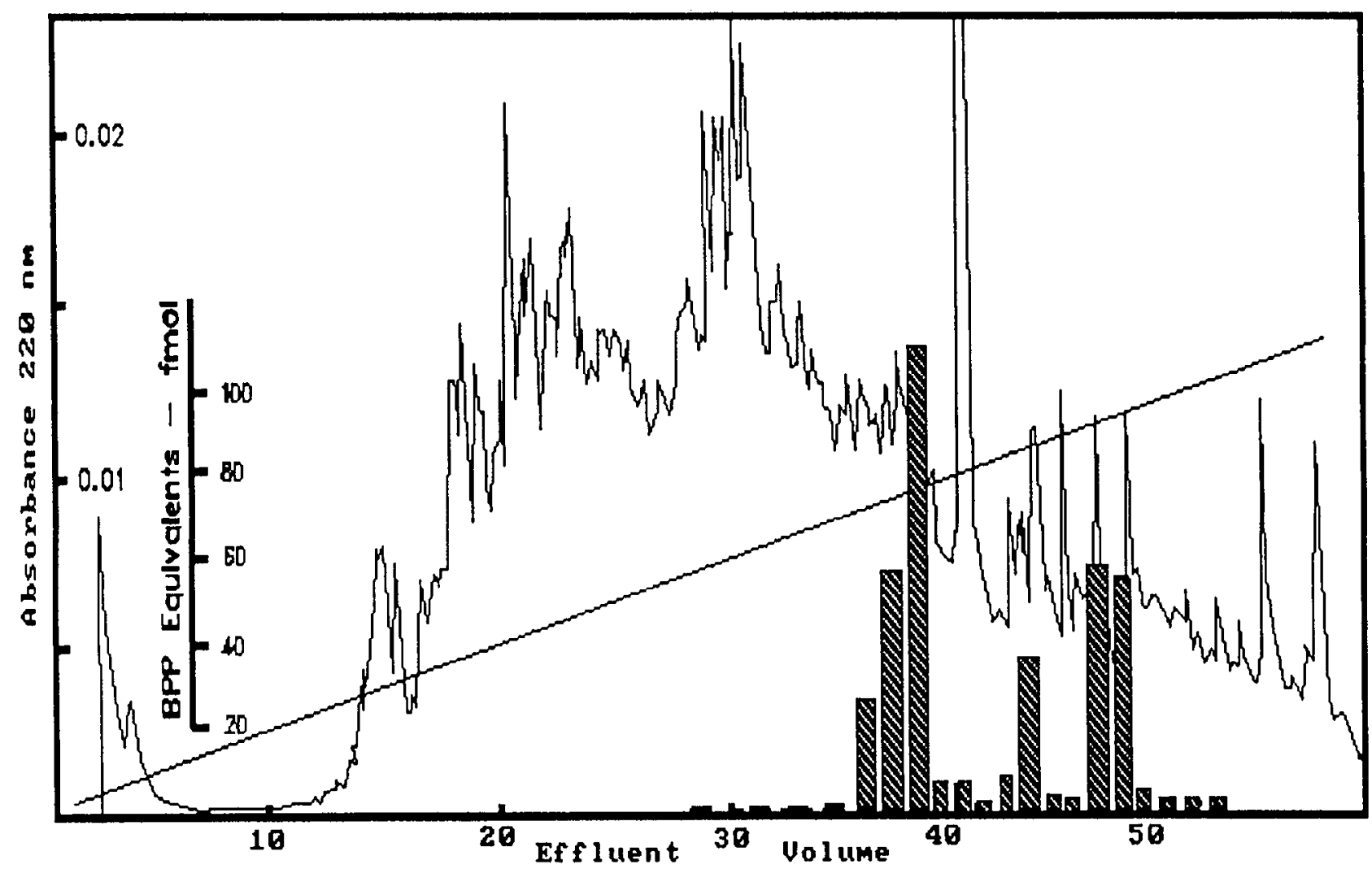

Figure 2. Reverse phase HPLC of the Sephadex pool indicated in Figure 1A. The acetonitrile gradient is represented by the line crossing the panel. The curve represents the absorption pattern at $220 \mathrm{~nm}$, and the bars correspond to PP immunoreactivity.

antisera used, the BPP antiserum gave rise to a weak staining of the meningeal border.

RPP antiserum. The RPP antiserum also appeared to label the same population of fibers in the lateral column that was recognized by the PYY and BPP antisera (Fig. 4C), although the RPP staining was usually less intense. In addition, dense fiber plexuses in the dorsal horn and in the lateral margin of the spinal cord showed immunoreactivity to RPP (Fig. $4 C$, arrowheads). Occasional RPP-ir cell bodies were observed in the central grey cell column (Fig. $4 C$, arrow). A rostral lesion diminished the dorsolateral RPP-ir fibers, whereas the other RPP-ir elements remained unchanged.

APP antiserum. The APP antiserum gave a comparatively weak and somewhat variable immunostaining in the spinal cord. A few APP-ir fibers usually were observed in the dorsal horn (Fig. 5C), overlapping with the distribution of NPY-ir fibers (cf. below). No APP-ir cell bodies were detected. Weakly fluorescent APP-ir fibers were sometimes observed in the lateral and ventromedial columns, although such staining was inconsistent.

Figure 6 summarizes the main patterns of PP-ir in the lamprey spinal cord. The lateral column contains fibers immunoreactive to PYY, BPP, and RPP, which are lost below a high spinal transection. The dorsal horn contains NPY-ir fibers that are unaffected by a high spinal lesion, and NPY-ir cell bodies are present lateral to the central canal. The APP and BPP-ir fibers in the dorsal horn overlap in part with the NPY-ir fibers (see below).

\section{Immunohistochemistry of the brain stem}

This section focuses on PYY and NPY labeling, since these 2 antisera appeared to give the most selective PP labeling.

PYY antiserum. The basal plate of rhombencephalon contained sparsely distributed PYY-ir fibers throughout its extent, whereas the alar plate showed very few PYY-ir fibers (Fig. 8, $C, E, F)$. A dense band of PYY-ir fibers was distributed ventral and medial to the trigeminal motor nucleus and the anterior rhombencephalic reticular nucleus (Figs. $8 F, 9 C$ ). The distribution of PYY-ir cell bodies is summarized in Figure 7 (left). Small (10-20 $\mu \mathrm{m}$ in diameter), rounded PYY-ir cells were present in the middle rhombencephalic reticular nucleus. Larger PYY-ir perikarya (20-40 $\mu \mathrm{m}$ in diameter) were located more rostrally, in the rostral portion of the trigeminal motor nucleus (Fig. $8 F$ ) and within and medial to the anterior rhombencephalic reticular nucleus (Fig. 9C). To test if these cells project to the spinal cord, PYY immunohistochemistry was combined with retrograde fluorescence tracing using FDA. Figures $8, F, G$, and $9, C, D$, show neurons in the trigeminal motor nucleus and the anterior rhombencephalic reticular nucleus, respectively, that contain both PYY-immunofluorescence and tracer fluorescence, implying a spinal projection. The majority of PYY-ir neurons in this region appeared to project to the spinal cord, although the double-labeled cells were not quantified.

The mesencephalon generally had a higher density of PYYir fibers (Fig. 10, $B, D$ ) compared to the rhombencephalon. Cell 

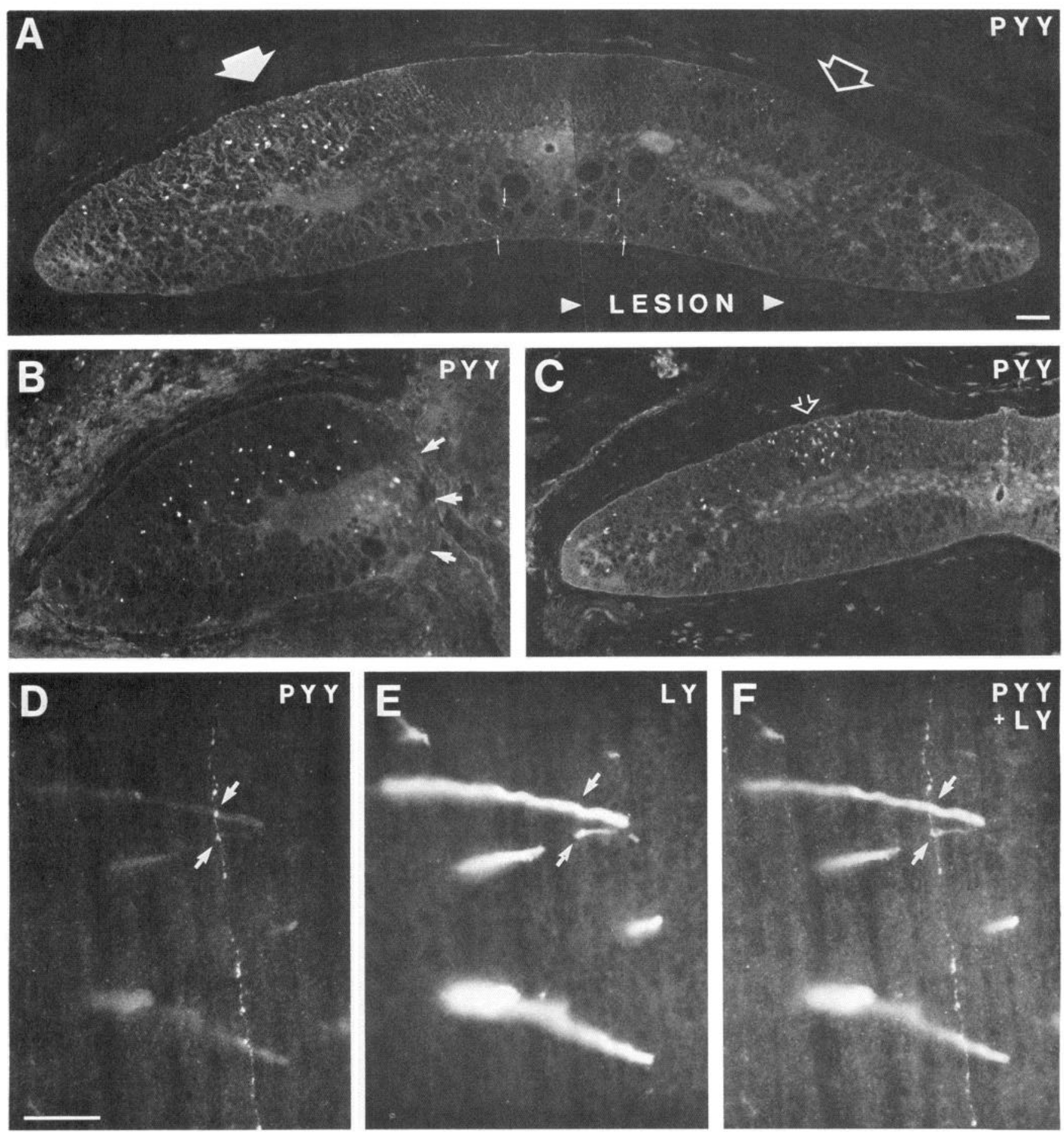

Figure 3. PYY-ir fibers in lamprey spinal cord. A, A transverse section from midbody level, caudal to a hemisection of the rostral spinal cord (right side, "lesion"). PYY-ir fibers are present in the dorsolateral region on the intact side (solid arrow) but are lost below the lesion (open arrow). Note some weakly immunoreactive fibers in the ventromedial column present in both control and lesion sides (thin arrows). B, Section from the rostral spinal cord (gill level) of the same animal, showing the extent of the lesion. Note that PYY-ir fibers are present in the intact hemisegment. Arrows indicate the medial extent of the lesion. ( $A$ and $B$, Lampetra fluviatilis). $C$, PYY-immunofluorescent fibers in a section from the caudal spinal cord. $D$ and $E$, Sequential exposures of a horizontal section from the lateral column (caudal spinal cord), including dendrites of a Lucifer yellow (LY)-stained giant interneuron and a PYY-ir fiber. $D$, PYY-rhodamine immunofluorescence. $E$, LY-fluorescence. $F$, Double exposure showing both types of fluorescence. Arrows indicate close appositions between PYY-ir boutonlike swellings and dendritic processes. ( $C-E$, Ichthyomyzon unicuspis). Scale bars, $50 \mu \mathrm{m}$. 


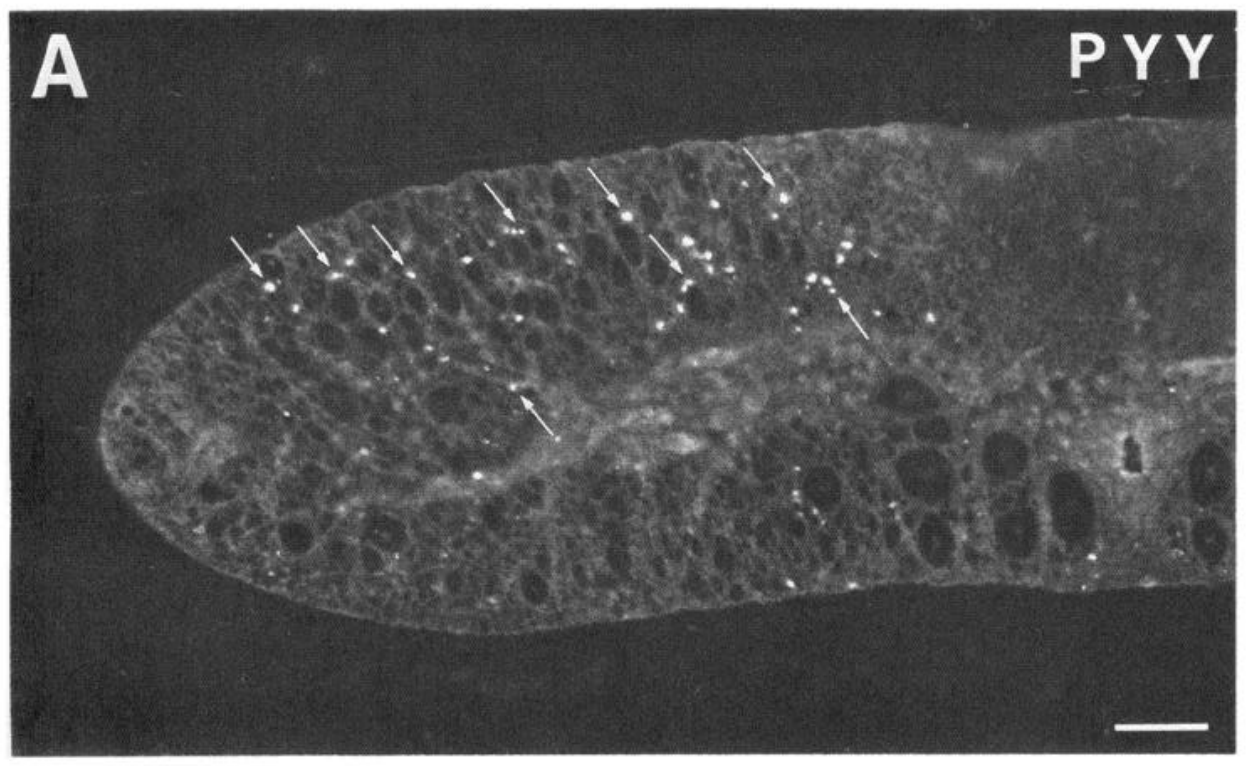

B

BPP

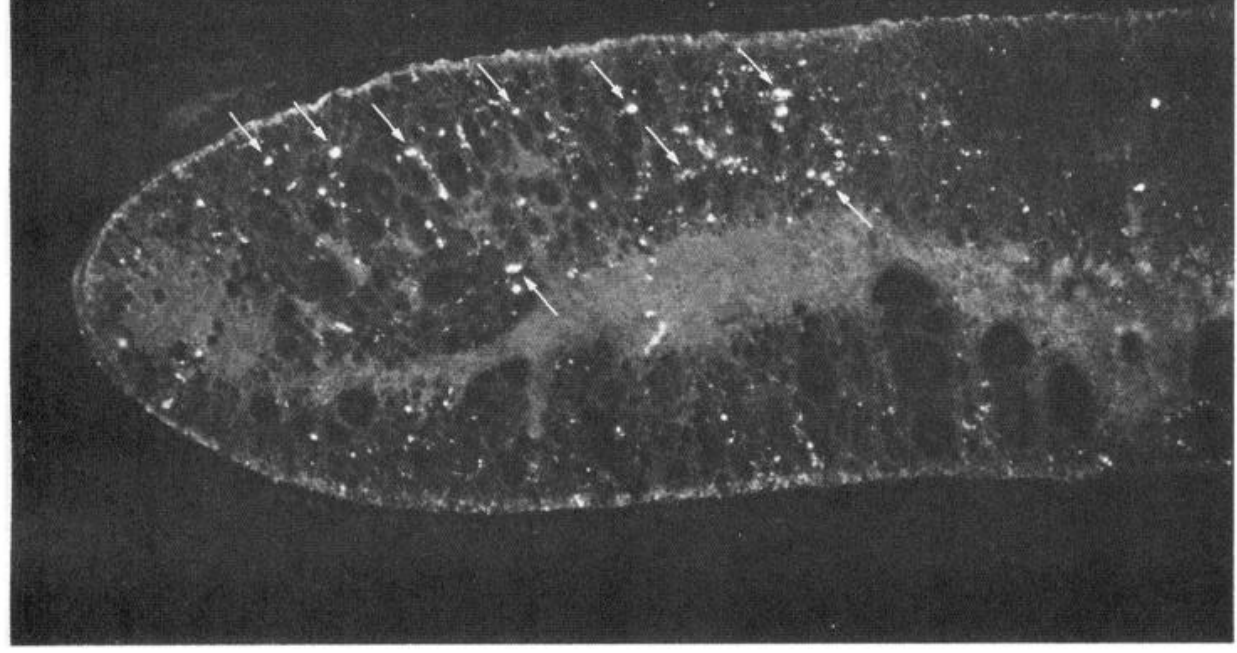

C

R P P

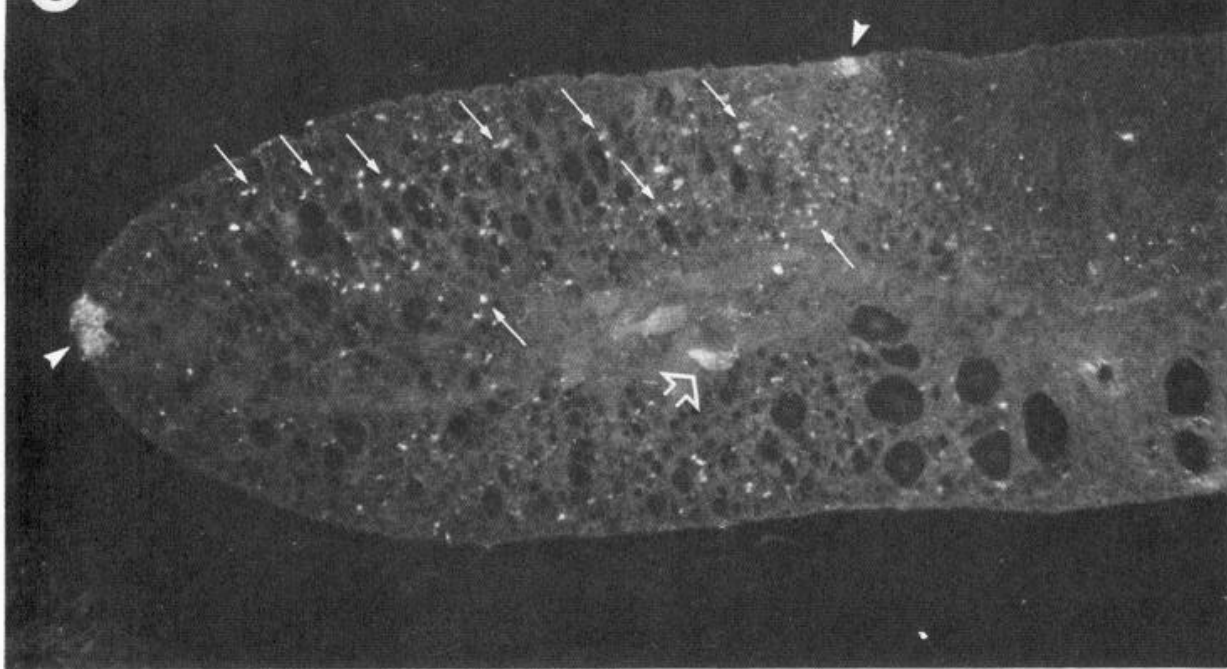

Figure 4. PYY and PP immunofluorescence in lamprey spinal cord. Three adjacent sections from the rostral spinal cord were incubated with antiserum raised against PYY $(A), \operatorname{BPP}(B)$, and RPP $(C)$, respectively. Arrows indicate immunoreactive fibers with a similar location in the 3 sections, which appear to react with all of the 3 antisera. RPP immunoreactivity is also present in fiber plexuses in the dorsal horn and lateral margin (arrowheads). (Lampetra fluviatilis). Scale bar, $50 \mu \mathrm{m}$. 

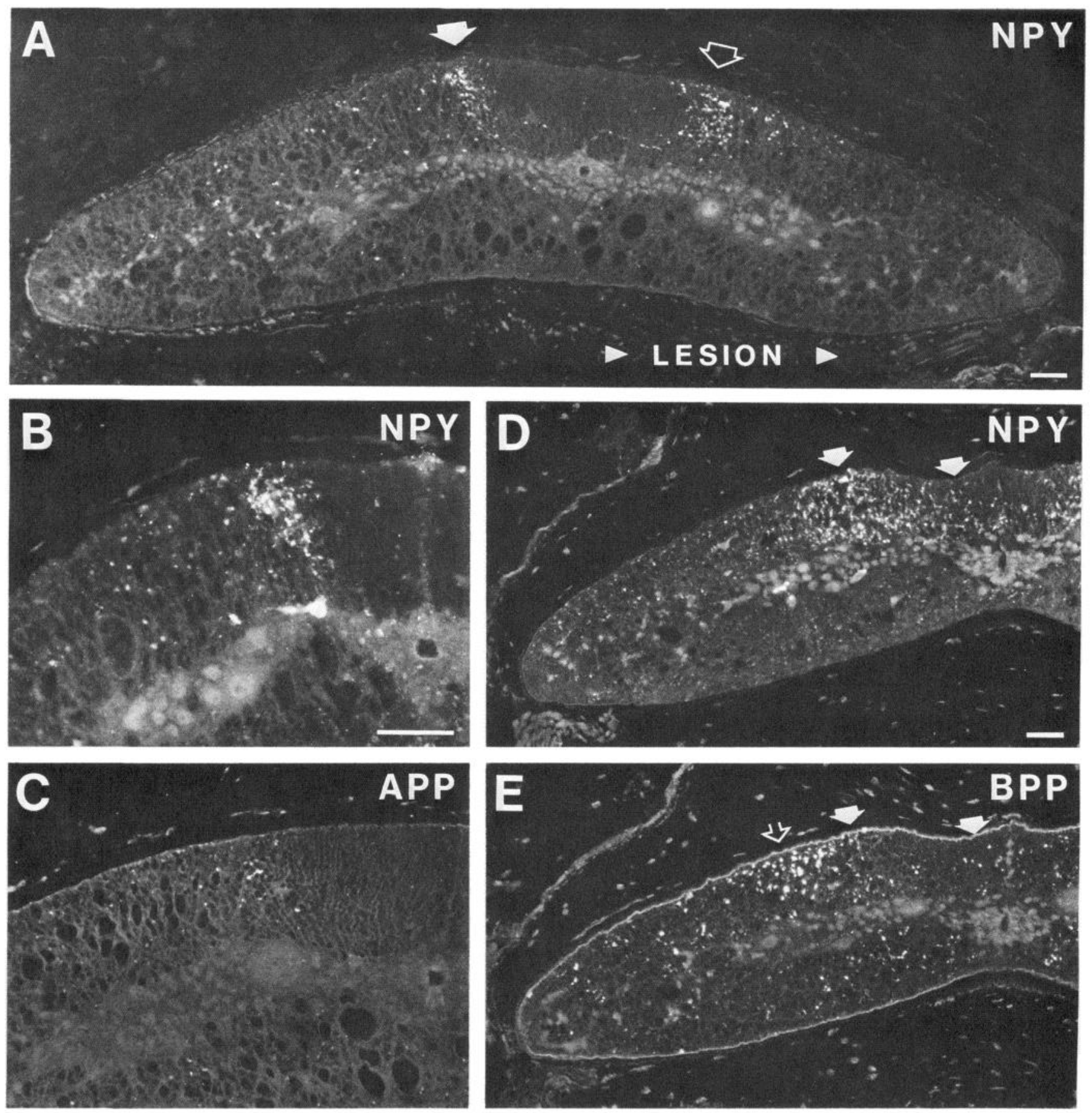

Figure 5. NPY and PP immunofluorescence in lamprey spinal cord. A, NPY immunofluorescence in a section from midbody level, caudal to a hemisection of the rostral spinal cord (same animal as in Fig. 3, $A, B$ ). Note that a similar fiber pattern in the dorsal horn is present on the intact (solid arrow) and lesioned (open arrow) side. The intact side has some dominance of immunoreactive fibers in the lateral column. $B$, NPYimmunoreactive cell body and fibers in the dorsal horn of the caudal spinal cord. $C$, APP-immunofluorescent fibers in the dorsal horn. $D$ and $E$, Adjacent sections from the caudal spinal cord incubated with antiserum against NPY $(A)$ and BPP $(B)$. The sections are adjacent to the section of Figure $3 C$. ( $A, B, D$ and $E$ : Ichthyomyzon unicuspis; $C$ : Lampetra fluviatilis). Scale bars, $50 \mu \mathrm{m}$.

bodies of small to intermediate size (diameter 15-30 $\mu \mathrm{m}$ ) were clustered in the reticular nucleus of mesencephalon (Fig. 10, $B$, $D$ ). Some PYY-ir fibers, which appeared to originate from the mesencephalic PYY-ir cell bodies, could be followed as they crossed the midline in the posterior commissure (Fig. 10D).

NPY antiserum. The rhombencephalon contained numerous NPY-ir fibers throughout its extent (Figs. $8, A, D ; 9 E$ ). The fiber density was highest in the lateral basal plate and the alar plate. The reticular formation contained comparatively few NPY-ir fibers. At the level of the anterior rhombencephalic reticular nucleus, a very dense NPY-ir plexus was present close to the midline and the ventral surface of rhombencephalon (Fig. $9 E$, open arrow). The distribution of neuropeptide Y-ir cell bodies is schematically displayed on the right side of Figure 7. Small 


\section{A-PYY A-RPP A-BPP}

A CON.

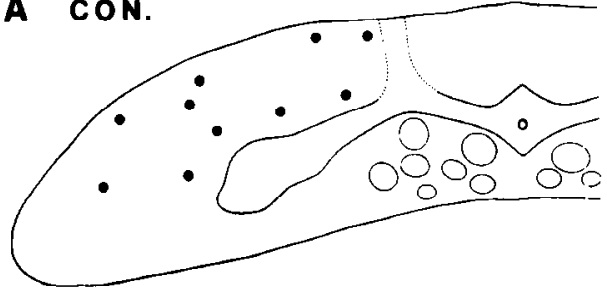

B LES.

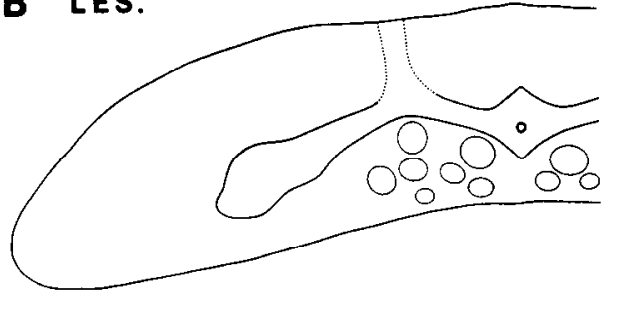

A-NPY

(A-APP)

(A-BPP)
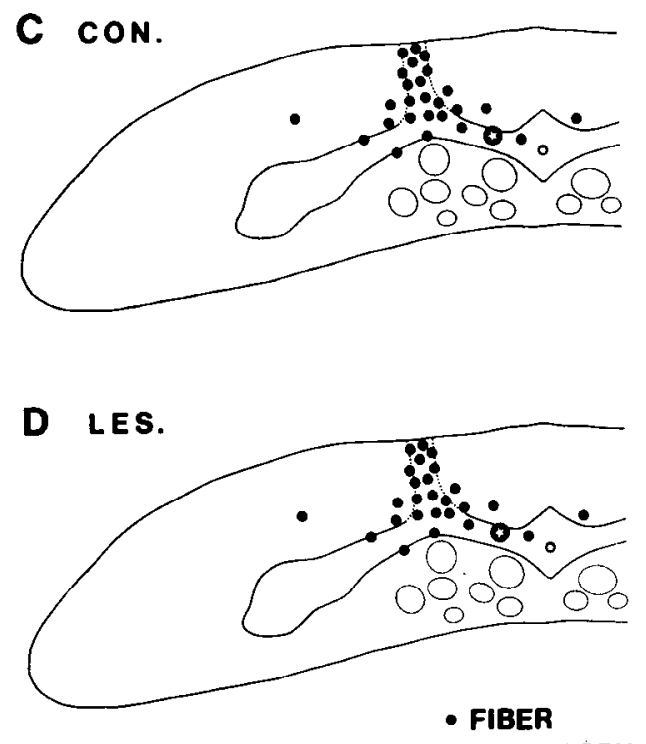

Figure 6. Schematic representation of PP-ir neuron systems in lamprey spinal cord. $A$, The dorsal part of the lateral column contains longitudinal $\mathrm{PYY}$-ir fibers recognized also by BPP and RPP antisera. These fibers, which are lost below a high spinal transection $(B)$, have bouton-like swellings in close apposition to motoneurons and giant interneurons. $C$, The dorsal horn area contains cell bodies (star on spot) and fibers recognized by NPY antiserum. This system, which appears to be partly recognized by APP and BPP antisera, is not affected by a high spinal lesion $(D)$.
NPY-ir cell bodies (diameter 10-20 $\mu \mathrm{m}$ ) were scattered near the medial border of the alar plate at the level of the vagal nucleus (Fig. 8A). Another group of small NPY-ir perikarya was present in the rostral alar plate along the octavolateralis area and extended medially into the dorsal aspect of the anterior rhombencephalic reticular nucleus (Fig. $9 E$ ).

In the mesencephalon, the highest density of NPY-ir fibers was observed in the dorsal and lateral parts. Small NPY-ir cell bodies were distributed dorsal to the mesencephalic reticular nucleus (see Fig. 7). No descending NPY-ir neurons could be detected with retrograde tracing, although a minor projection cannot be excluded, since the retrograde labeling may have been incomplete (cf. Brodin et al., 1988b).

Other PP antisera. The BPP and RPP antisera labeled cell bodies with a distribution similar to the PYY-ir cells (Fig. 7). Thus, RPP-ir and BPP-ir cells were present in the middle and anterior rhombencephalic reticular nucleus (Fig. $9 A$ ) and in the mesencephalic reticular nucleus (Fig. $10 A, C$ ). The spinal projection of the anterior rhombencephalic group was confirmed by combining BPP or RPP staining with fluorescence tracing (Fig. 9, $A, B$ ).

The BPP labeling also showed a clear overlap with NPY-ir structures (cf. Figs. 8, $A, B ; 9, A, E$ ). The perikaryal BPP labeling was, however, often weaker compared to that produced by the NPY antiserum. The APP staining in the brain stem overlapped closely with the NPY labeling (cf. Fig. 9, $E$ and $F$ ) but was usually less intense.

Retina. Figurc $10 E$ shows presumed amacrine cells in the retina stained by NPY antiserum (cf. Negishi et al., 1986). The BPP antiserum produced a similar but weaker labeling (Fig. 10F). No PYY-ir was observed in the retina (Fig. 10G).

\section{Discussion}

The results of this study establish the presence of PP-like peptides in the CNS of lampreys, as has been suggested by preliminary immunohistochemical studies on spinal cord (VanDongen et al., 1985) and retina (Negishi et al., 1986). Pancreatic polypeptide-like material was detected in RIA with an antiserum directed to the C-terminal hexapeptide of BPP. This type of antiserum is also known to recognize PPs from pancreatic tissue of lower vertebrates, such as salmon, alligator gar, and bullfrog (Kimmel et al., 1986; Pollock et al., 1987, 1988). As judged from the complex elution profile on HPLC, the PP immunoreactivity in lamprey $\mathrm{CNS}$ is composed of several molecular forms. The definition of the specific chemical nature of these forms, however, remains to be defined in further studies.

The immunohistochemical data suggest that PP-like compounds are stored in at least two separate populations of neurons (see schematic overview in Fig. 11). Whereas nerve cells in the spinal dorsal horn and the sensory alar plate of the lateral brain stem reacted with antisera toward NPY and APP, the PYY and RPP antisera labeled neurons in the brain stem reticular formation. The fact that both populations of neurons reacted with the BPP antiserum supports the interpretation that the 2 types of immunohistochemically detectable PP immunoreactivity have common immunogenic determinants and that, perhaps, they both can be reflected as bovine C-terminal PP immunoreactivity in RIA (cf. Taylor et al., 1988).

Although the codistribution of PP-immunoreactivities can possibly be due to colocalization of different PP-ir compounds, we will assume here that each of the main patterns of PP labeling corresponds to one peptide. For simplicity we refer to the NPY/ APP/BPP staining as "type 1" immunoreactivity and to the PYY/RPP/BPP pattern as "type 2" immunoreactivity. With this interpretation, it seems likely that the 2 postulated peptides belong to the PP family, since each of them would have been recognized by as many as three different PP antisera, which minimizes the risk of cross-reactivity with other peptide families. Furthermore, the staining specificities of the NPY and PYY antisera were confirmed in preabsorption controls with corresponding mammalian peptides.

Two dense fiber plexuses, in the spinal dorsal horn and in the 


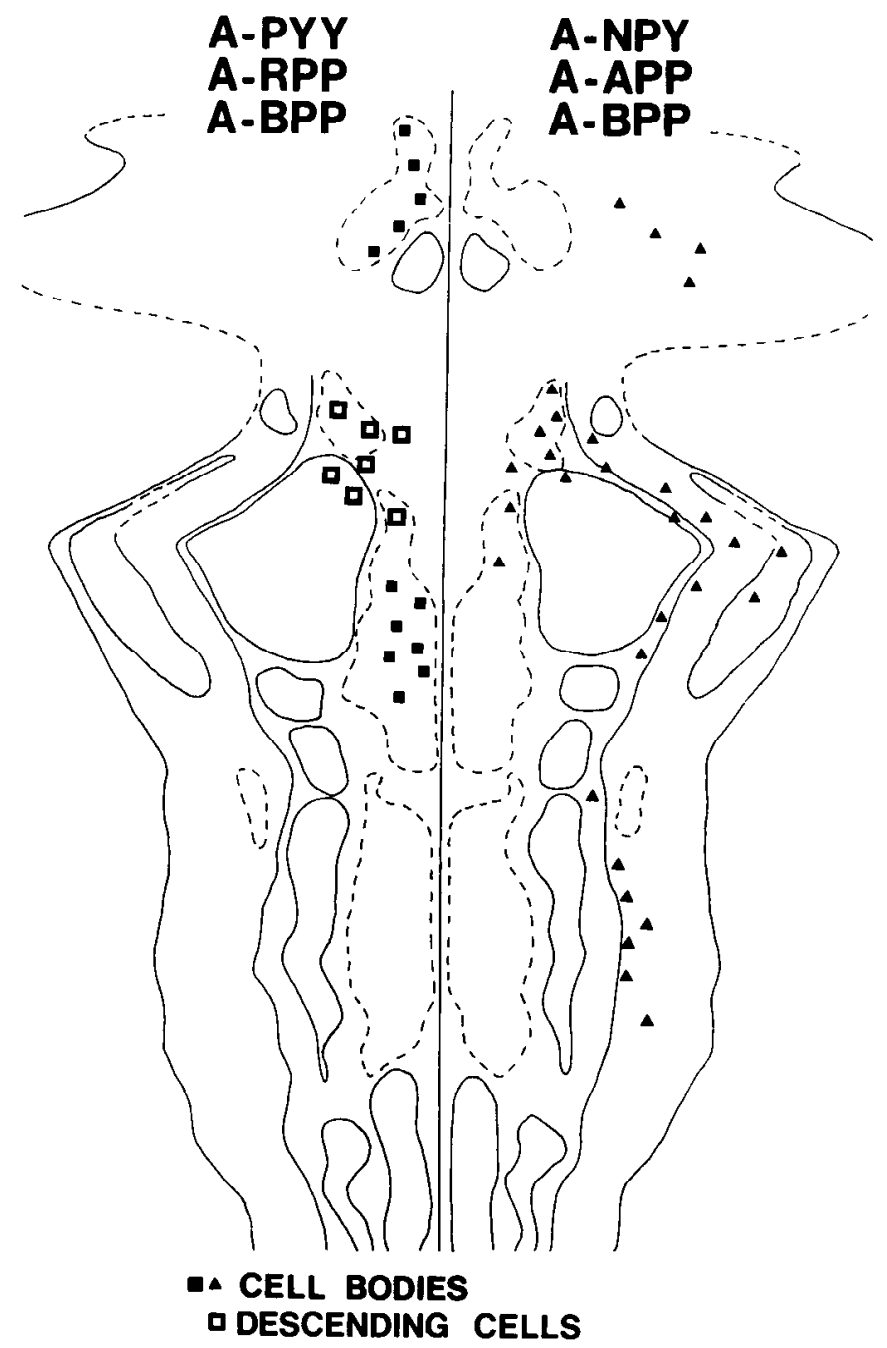

Figure 7. Schematic representation of the distribution of PP-ir cell bodies as they project onto a topological map of the brain stem (modified from Nieuwenhuys, 1972), Left, Filled squares indicate small to medium-sized PYY-ir cells in the middle rhombencephalic reticular nucleus and in the mesencephalic reticular nucleus. Open squares indicate large to medium-sized cell bodies with a spinal projection, located in the anterior rhombencephalic reticular nucleus and trigeminal motor nucleus. All 3 groups were also labeled by BPP and RPP antisera. Right, Triangles indicate NPY-ir cell bodies, also recognized by APP and BPP antisera. The cells are located in the caudal rhombencephalic alar plate, octavolateralis area, anterior rhombencephalic reticular nucleus, and dorsal to the mesencephalic reticular nucleus. lateral spinal cord, were labeled by the RPP antiscrum but not by any of the other PP antisera. Whether this RPP immunoreactivity corresponds to a PP-like compound or whether it is due to cross-reactivity with one of the several other peptides (neurotensin-, somatostatin-, and tachykinin-like peptides) with this localization (VanDongen et al., 1986; Buchanan et al., 1987) cannot be determined at present.

\section{Comparisons with neuronal PPs in other species}

Type 1 immunoreactivity. The immunological properties of the type 1-ir material suggest that it may represent a peptide resembling mammalian NPY (cf. Danger et al., 1985; Perroteau et al., 1988; Vallarino et al., 1988). The lamprey peptide reacted with an NPY antiserum directed to the N-terminal portion of the peptide, which makes it unlikely that this antiserum would cross-react with other PPs (Lundberg et al., 1984). Furthermore, the type 1 peptide appeared to be recognized by APP and BPP antisera, both of which have been found to label NPY-containing neurons in the rat CNS (Hökfelt et al., 1981; Lundberg et al., 1984; see also DiMaggio et al., 1985; DeQuidt and Emson, 1986a). The intensity of the APP and BPP immunoreactivities differed somewhat between the spinal cord and brain stem. In the latter, they showed a clear overlap with the NPY labeling, whereas in the spinal cord, the BPP and APP antisera produced a comparatively weak staining of NPY-ir structures. These findings could reflect differences between the peptides present in the spinal cord and in the brain stem. It would seem more likely, however, that they result from variations of the peptide levels in the two regions.

Similarities in the organization of lamprey type 1-ir neurons and NPY-containing neurons in other species are also in keeping with a homology to NPY. As an example, the type 1-ir fibers in the lamprey spinal cord were restricted to the dorsal horn, with only few fibers present in other regions. The fibers appeared to originate from cell bodies located lateral to the central canal. A similar distribution of NPY-ir fibers and perikarya has been described in the spinal cord of frog (Rana ridibunda; Danger et al., 1985) and several mammals (Allen et al., 1984; Gibson et al., 1984; Sasek and Elde, 1985; Krukoff, 1987), although supraspinal NPY neurons may, in addition, contribute to the innervation of the spinal cord (Everitt et al., 1984; Chronwall et al., 1985). Another example is the distribution of type 1-ir neurons and processes in the rhombencephalic alar plate. A similar innervation with NPY-ir structures is present in the rhomben-

Figure 8. PP-immunofluorescence in the lamprey rhombencephalon. $A-C$, Adjacent sections from the level of the caudal pole of the posterior rhombencephalic reticular nucleus, incubated with antiserum to NPY $(A)$, BPP $(B)$, and PYY $(C)$, respectively. Immunoreactive cell bodies are indicated by arrows. Note the similar distribution of NPY-ir and BPP-ir fibers. $D$ and $E$, Adjacent sections at the level of the middle rhombencephalic reticular nucleus incubated with NPY $(D)$ and PYY $(E)$ antiserum. ( $A-E$ : Ichthyomyzon unicuspis). $F$ and $G$, Section from the trigeminal motor nucleus. F, PYY-immunofluorescence (TRITC). $G$, FDA fluorescence in the same section, following FDA injection in the spinal cord. The arrow indicates a double-labeled cell body. ( $F, G$ : Lampetra fluviatilis). Scale bar, $50 \mu \mathrm{m}$.

Figure 9. PP immunofluorescence in lamprey rhombencephalon combined with retrograde fluorescence tracing from the spinal cord. Four adjacent sections from the anterior rhombencephalic reticular nucleus (1-4) were incubated with antiserum to BPP (1), PYY (2), NPY (3), and APP (4). $A$, BPP immunofluorescence (TRITC) of section $1 . B$, Retrograde FDA fluorescence of the same section. Correspondingly, $C$ and $D$ show PYY-ir and FDA fluorescence of section 2. Arrows indicate double-labeled cell bodies. The apparent difference in shape is due to partial overlap of nondoublelabeled structures. The NPY $(E)$ and APP $(F)$ antisera labeled smaller cell bodies (short arrows) that did not accumulate FDA from the spinal cord. Note the similar distribution of NPY and APP-ir and the overlap of BPP staining with both the PYY-pattern and with the NPY-APP staining patterns (Lampetra fluviatilis). Scale bar, $50 \mu \mathrm{m}$.

Figure 10. PP immunoreactivities in lamprey mesencephalon and retina. $A-C$, Adjacent sections from the mesencephalic reticular nucleus incubated with antiserum to RPP $(A)$, PYY $(B)$, and BPP $(C)$. Note the similar location of cell bodies (arrows) in the 3 sections. $D$, PYY-ir in a section including the mesencephalic reticular nucleus and the posterior commissure. Arrow indicates immunoreactive fibers in the commissure. $E-G$, Sections of the retina incubated with NPY $(E)$, BPP $(F)$, and PYY $(G)$ antisera, respectively. Cells of the inner nuclear layer show an intense NPY. ir and a weak BPP-ir, while PYY-ir is lacking. (Lampetra fluviatilis). Scale bar, $50 \mu \mathrm{m}$. 


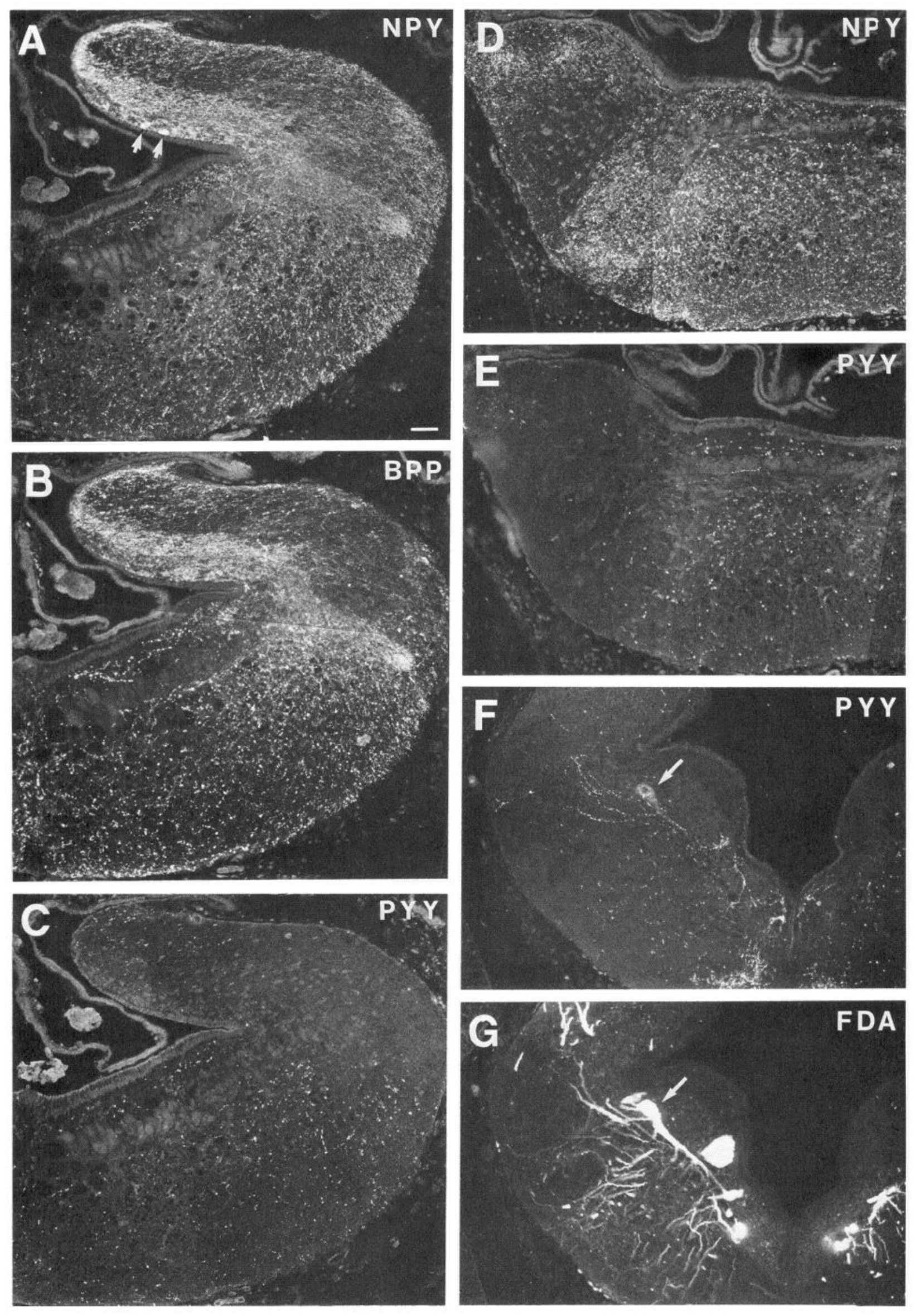



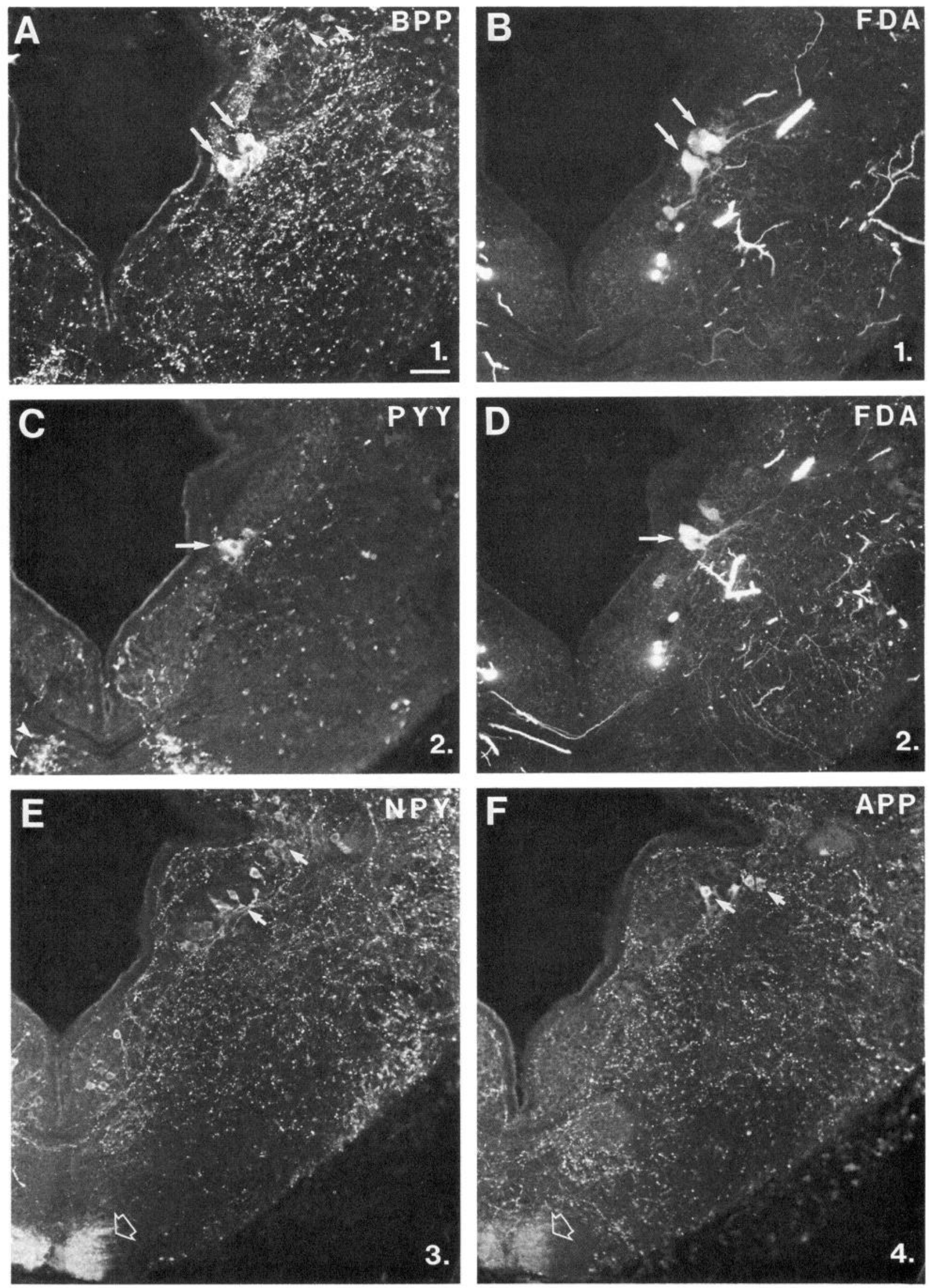

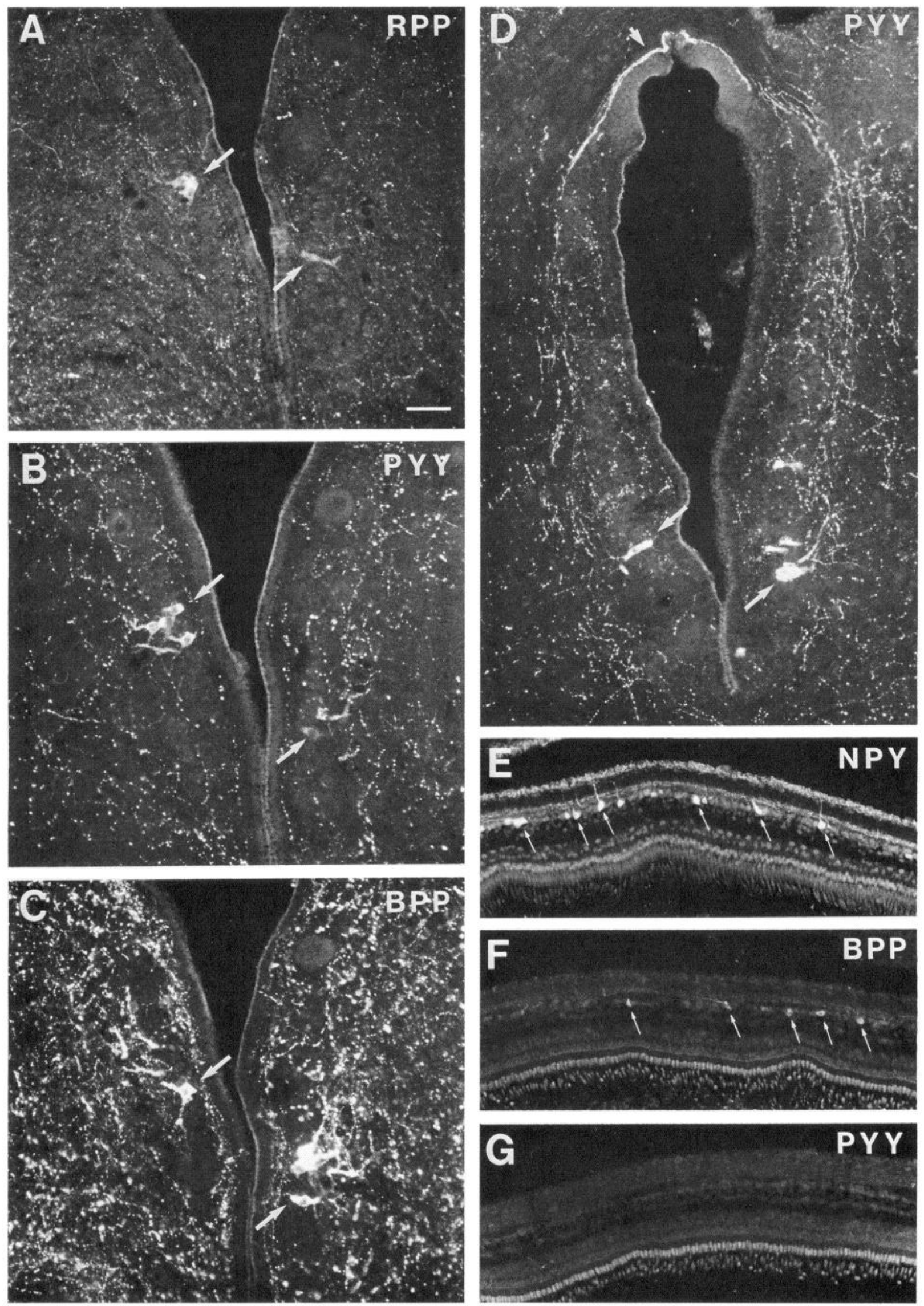


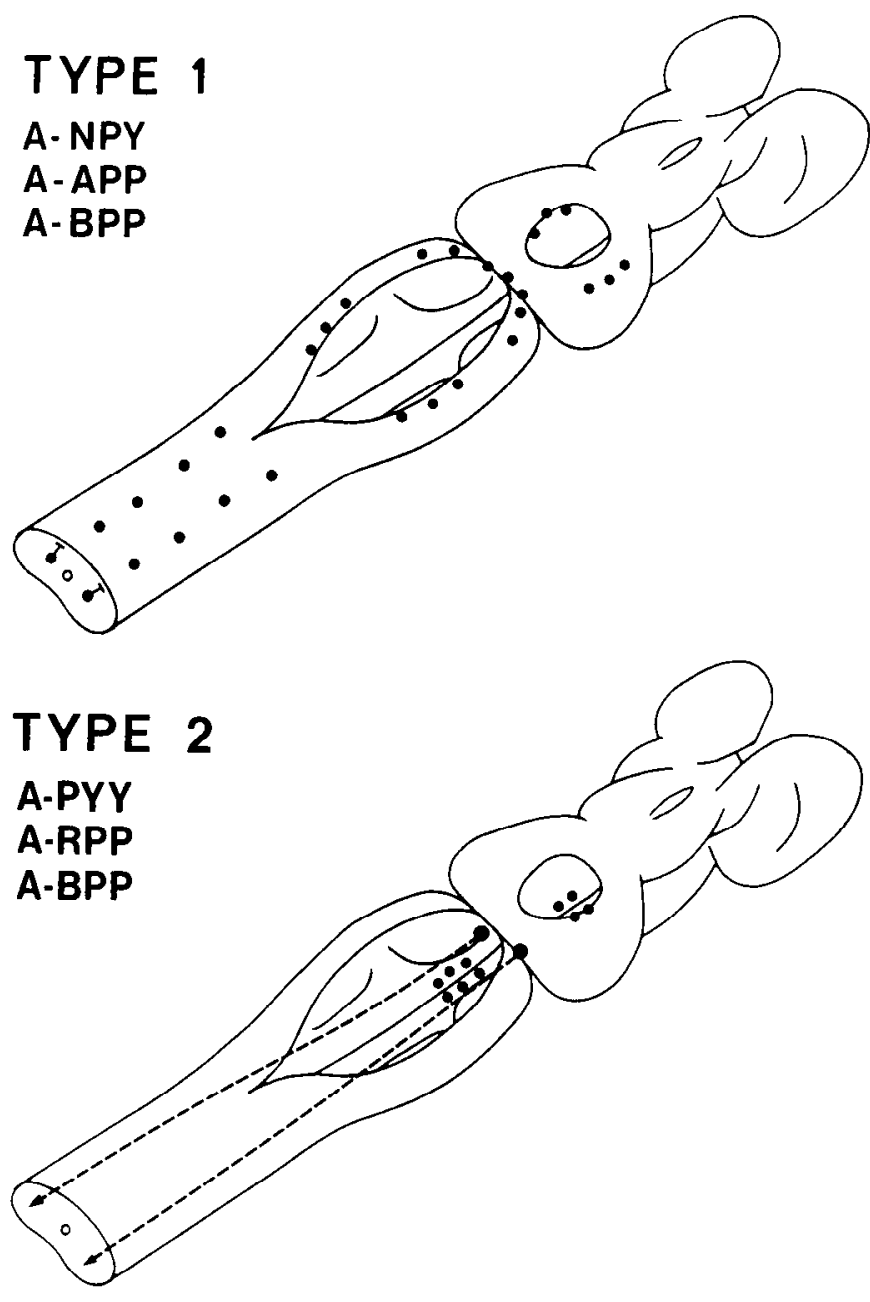

Figure 11. Schematic representation of PP-immunoreactive neurons in the lamprey brain stem and spinal cord. The "type 1"-ir neurons, recognized by NPY, APP, and BPP antisera, are distributed in "sensory" areas of the dorsal spinal cord and the lateral brain stem. The "type 2" (PYY, RPP, and BPP)-ir neurons are localized in the reticular motor area of the medial brain stem. Type 2-ir reticulospinal cells in the anterior reticular nucleus descend in the dorsolateral spinal column and appear to synapse on spinal motoneurons and certain interneurons (see text).

cephalic alar plate of the crested newt (Triturus cristatus; Perroteau et al., 1988). Notably, the NPY-ir material in the newt brain is partly similar in molecular size to mammalian NPY.

Type 2 immunoreactivity. The type 2 peptide differs immunologically from the type 1 peptide, since it did not react with the NPY or APP antisera. It may, however, share common determinants, since it was recognized by the BPP antiserum and perhaps also by the C-terminal PP antiserum used in RIA (see above). The lamprey CNS thus appears to contain a PP distinct from NPY, which can be selectively detected by antiserum to PYY. Peptide YY-ir compounds that are not recognized by NPY antiserum have been detected in the CNS of frog, lizard, and rat (Lundberg et al., 1984; Broomée et al., 1985; Böttcher et al., 1985; Ekman et al., 1986). Interestingly, the organization of PYY-ir neurons in these animals shows similarities to that of type 2 -ir cells in lamprey. The type 2 -ir cell bodies were observed in the mesencephalic reticular nucleus and in the middle and anterior rhombencephalic reticular nuclei of the rostral medulla.
The latter group project to the lateral spinal cord, as judged from the retrograde tracing and lesion experiments. In frog (Rana temporaria), as well as in rat, PYY-ir cell bodies are present in the reticular formation of the rostral medulla, and the fiber distribution suggests that these neurons project to the spinal cord (Broomée et al., 1985; Böttcher et al., 1985; Ekman et al., 1986). It is unclear whether the PYY immunoreactivity in the frog and rat CNS corresponds to true PYY or represents a yet unidentified PP (Tatemoto 1989).

\section{Functional implications}

The differences in distribution of the two putative PP systems in lamprey suggest involvement in separate functions. The type 1 ("NPY")-ir neurons were present in areas involved in processing of sensory inflow, such as the retina (e.g., goldfish; Stell, 1985), the dorsal horn of the spinal cord, and the rostral and caudal rhombencephalic alar plate, where afferents from the different cranial nerves and the spinal cord terminate (Nieuwenhuys, 1977; Rovainen, 1979; Dubuc and Grillner, 1987). Considering the similarities with other species (see above), this "sensory" localization of a possible NPY homolog in an agnathan may imply that NPY-like peptides became involved with sensory functions at an early stage in vertebrate evolution.

In contrast, the type 2 ("PYY")-ir neurons were found in areas primarily subserving motor functions. All cell bodies were observed within or adjacent to the rhombencephalic and mesencephalic reticular formation, regions that exert a direct control of somatic motoneurons and premotor interneurons (Nieuwenhuys, 1972; Rovainen, 1979; Brodin et al., 1988b). The reticulospinal type 2 -ir system may exert a monosynaptic influence on spinal motoneurons, since immunoreactive fibers were observed in close apposition to motoneuron dendrites. It may, however, also affect the sensory transmission, since close appositions were seen on large spinobulbar neurons (giant interneurons) that transmit sensory information.

The type $2 \mathrm{PP}$ is now the fourth putative transmitter to be identified in a reticulospinal projection in lamprey. Descending cholecystokinin- and 5-hydroxytryptamine-ir neurons have been detected in the posterior and anterior rhombencephalic reticular nuclei, whereas neurons using excitatory amino acid transmission have been localized throughout the reticular formation (for review see Brodin et al., 1988b). Further comparative studies will be required to determine the phylogenetic relationships of these systems, but their chemical and anatomical similarities with reticulospinal systems in other animals suggest that they may represent primitive traits present in most vertebrates.

\section{References}

Allen, Y. S., T. E. Adrian, J. M. Allen, K. Tatemoto, T. J. Crow, S. R. Bloom, and J. M. Polak (1983) Neuropeptide Y distribution in the rat brain. Science 221: 877-879.

Allen, J. M., S. J. Gibson, T. E. Adrian, J. M. Polak, and S. R. Bloom (1984) Neuropeptide $Y$ in human spinal cord. Brain Res. 308: 145148.

Böttcher, G., G. Skagerberg, R. Ekman, R. Håkansson, and F. Sundler (1985) PYY-like peptides in the central and peripheral nervous system of a frog and a lizard. Peptides 6(Suppl. 3): 215-221.

Brodin, L., J. T. Buchanan, T. Hökfelt, S. Grillner, J. F. Rehfeld, P. Frey, A. A. J. Verhofstad, G. J. Dockray, and J. H. Walsh (1988a) Immunohistochemical studies of cholecystokinin-like peptides and their relation to 5-HT, CGRP and bombesin immunoreactivities in the brain stem and spinal cord of lampreys. J. Comp. Neurol. 271: $1-18$.

Brodin, L., S. Grillner, R. Dubuc, Y. Ohta, S. Kasicki, and T. Hökfelt 
(1988b) Reticulospinal neurons in lamprey: Transmitters, synaptic interactions and their role during locomotion. Arch. Ital. Biol. 126: 317-345.

Brodin, L., Y. Ohta, T. Hökfelt, and S. Grillner (1988c) Immunohistochemical studies of pancreatic polypeptide-like compounds in the lamprey CNS. Acta Physiol. Scand. 132: 15A.

Broomée, M., T. Hökfelt, and L. Terenius (1985) Peptide YY (PYY)immunoreactive neurons in the lower brain stem and spinal cord of rat. Acta Physiol. Scand. 125: 349-352.

Buchanan, J. T., L. Brodin, T. Hökfelt, P. A. M. VanDongen, and S. Grillner (1987) Survey of neuropeptide-like immunoreactivity in the lamprey spinal cord. Brain Res. 408: 299-302.

Chronwall, B. M., D. A. DiMaggio, V. J. Massari, V. M. Pickel, D. A. Ruggiero, and T. L. O'Donohue (1985) The anatomy of neuropeptide $\mathrm{Y}$-containing neurons in rat brain. Neuroscience 15: 1159-1181.

Danger, J. M., J. Guy, M. Benyamina, S. Jegou, F. Leboulenger, J. Coté, M. C. Tonon, G. Pelletier, and H. Vaudry (1985) Localization and identification of neuropeptide Y (NPY)-like immunoreactivity in the frog brain. Peptides 6: 1225-1236.

DeQuidt, M. E., and P. C. Emson (1986a) Distribution of neuropeptide Y-like immunoreactivity in the rat central nervous system. I. Radioimmunoassay and chromatographic characterization. Neuroscience 18: 527-543.

DeQuidt, M. E., and P. C. Emson (1986b) Distribution of neuropeptide $\mathrm{Y}$-like immunoreactivity in the rat central nervous system. II. Immunohistochemical analysis. Neuroscience 18: 545-618.

DiMaggio, D. A., B. M. Chronwall, K. Buchanan, and T. L. O'Donohue (1985) Pancreatic polypeptide immunoreactivity in rat brain is actually neuropeptide Y. Neuroscience 15 : 1149-1157.

Dubuc, R., and S. Grillner (1987) Inputs to the reticulospinal neurons of the nucleus reticularis posterior in the lamprey. Neuroscience 22: S640.

Duve, H., A. Thorpe, N. Lazarus, and P. J. Lowry (1982) A neuropeptide of the blowfly Calliphora erytrocephala with an amino acid composition homologous with vertebrate pancreatic polypeptide. Biochem. J. 197: 767-770.

Ekman, R., C. Wahlestedt, G. Böttcher, F. Sundler, R. Håkansson, and P. Panula (1986) Peptide YY-like immunoreactivity in the central nervous system of the rat. Regul. Pept. 16: 157-168.

Everitt, B., T. Hökfelt, L. Terenius, K. Tatemoto, V. Mutt, and M. Goldstein (1984) Differential co-existence of neuropeptide Y (NPY) with catecholamines in the central nervous system of the rat. Neuroscience 11: 443-462.

Gibson, S. J., J. M. Polak, J. M. Allen, T. E. Adrian, J. S. Kelly, and S. R. Bloom (1984) The distribution and origin of a novel brain peptide, neuropeptide $Y$, in the spinal cord of several mammals. J. Comp. Neurol. 227: 78-91.

Gimlich, R. L., and J. Brown (1985) Improved fluorescent compounds for tracing cell lineage. Dev. Biol. 109: 509-514.

Glover, J. C., G. Petursdottir, and J. K. S. Jansen (1986) Fluorescent dextran-amines used as axonal tracers in the nervous system of the chicken embryo. J. Neurosci. Methods 18: 243-254.

Grillner, S., P. Wallén, N. Dale, L. Brodin, J. Buchanan, and R. Hill (1987) Transmitters, membrane properties and network circuitry in the control of locomotion in the lamprey. Trends Neurosci. 10:3441.

Hökfelt, T., J. M. Lundbcrg, G. Jancso, and J. Kimmel (1981) Avian pancreatic polypeptide (APP) immunoreactive neurons in the spinal cord and spinal trigeminal nucleus. Peptides 2: 81-87.

Inui, A., N. Mizuno, M. Ooya, K. Suenaga, H. Morioka, T. Ogawa, M. Ishida, and S. Baba (1985) Cross-reactivities of neuropeptide $Y$ and peptide YY with pancreatic polypeptide antisera: Evidence for the existence of pancreatic polypeptide in the brain. Brain Res. 330: 386389.

Johnson, D. G., and G. M. De C. Nogueira Araujo (1981) A simple method of reducing the fading of immunofluorescence during microscopy. J. Immunol. Methods 43: 349.

Kimmel, J. R., H. G. Pollock, and R. L. Hazelwood (1968) Isolation and characterization of chicken insulin. Endocrinology 83: 13231330.

Kimmel, J. R., J. Hayden, and H. G. Pollock (1975) Isolation and characterization of a new pancreatic polypeptide hormone. J. Biol. Chem. 250: 9369-9376.

Kimmel, J. R., E. M. Plisetskaya, H. G. Pollock, J. W. Hamilton, J. B. Rouse, K. E. Ebner, and A. B. Rawitch (1986) Structure of a peptide from coho salmon endocrine pancreas with homology to neuropeptide Y. Biochem. Biophys. Res. Commun. 141: 1084-1091.

Krukoff, T. L. (1987) Neuropeptide Y-like immunoreactivity in cat spinal cord with special reference to autonomic areas. Brain Res. 415: 300-308.

Lin, T. M., and R. E. Chance (1974) Candidate hormones of the gut: Bovine pancreatic polypeptide (BPP) and avian pancreatic polypeptide (APP). Gastroenterology 67: 737-738.

Lundberg, J. M., K. Tatemoto, L. Terenius, P. M. Hellström, V. Mutt, T. Hökfelt, and B. Hamberger (1982) Localization of peptide YY (PYY) in gastrointestinal endocrine cells and effects on intestinal blood flow and motility. Proc. Natl. Acad. Sci. USA 79: 4471-4475.

Lundberg, J. M., L. Terenius, T. Hökfelt, and K. Tatemoto (1984) Comparative immunohistochemical and biochemical analysis of pancreatic polypeptide-like peptides with special reference to presence of neuropeptide $\mathrm{Y}$ in central and peripheral neurons. J. Neurosci. 4: 2376-2386.

Negishi, K., H. Kiyama, S. Kato, T. Teranishi, S. Hatakenaka, Y. Katayama, N. Miki, and M. Tohyama (1986) An immunohistochemical study of the river lamprey retina. Brain Res. 362: 389-393.

Nieuwenhuys, R. (1972) Topological analysis of the brain stem of the lamprey Lampetra fluviatilis. J. Comp. Neurol. 145: 165-178.

Nieuwenhuys, R. (1977) The brain of the lamprey in comparative perspective. Ann. NY Acad. Sci. 229: 97-145.

Ohta, Y., L. Brodin, S. Grillner, T. Hökfelt, and J. H. Walsh (1988) Possible target neurons of the reticulospinal cholecystokinin (CCK) projection to the lamprey spinal cord: Immunohistochemistry combined with intracellular staining with Lucifer yellow. Brain Res. 445: $400-403$.

Perroteau, I., J. M. Danger, S. Biffo, G. Pelletier, H. Vaudry, and A. Fasolo (1988) Distribution of neuropeptide Y-like immunoreactivity in the brain of the crested newt. J. Comp. Neurol. 275: 309-325.

Pettinga, C. W. (1958) Insulin. Biochem. Prep. 6: 28-31.

Pollock, H. G., and J. R. Kimmel (1981) Immunoassay for avian pancreatic polypeptide and applications in chickens. Gen. Comp. Endocrinol. 45: 386-394.

Pollock, H. G., J. R. Kimmel, J. W. Hamilton, J. B. Rouse, K. E. Ebner, V. Lance, and A. B. Rawitch (1987) Isolation and structures of alligator gar (Lepisosteus spatula) insulin and pancreatic polypeptide. Gen. Comp. Endocrinol. 67: 375-382.

Pollock, H. G., J. W. Hamilton, J. B. Rouse, K. E. Ebner, and A. B. Rawitch (1988) Isolation of peptide hormones from the pancreas of the bullfrog (Rana catesbiana): Amino acid sequences of pancreatic polypeptide, oxyntomodulin, and two glucagon-like peptides. J. Biol. Chem. 15: 9746-9751.

Rovainen, C. M. (1979) Neurobiology of lampreys. Physiol. Rev. 59: $1007-1077$

Sasek, C. A., and R. P. Elde (1985) Distribution of neuropeptide Y-like immunoreactivity and its relationship to FMRF-amide-like immunoreactivity in the sixth lumbar and first sacral spinal cord segments of the rat. J. Neurosci. 5: 1729-1739.

Schober, W. (1964) Vergleichend-anatomische Untersuchungen am Gehirn der Larven und adulten Tiere von Lampetra fluviatilis (Linné, 1758) und Lampetra planeri (Bloch, 1784). J. Hirnforsch. 7: 9-209.

Stell, W. K. (1985) Putative peptide transmitters, amacrine cell diversity and function in the inner plexiform layer. In Neurocircuitry of the Retina, A. Gallcgo and P. Gouras, cds., pp. 170-187, Elsevier, New York.

Sundler, F., R. Håkansson, J. Alumets, and B. Walles (1977) Neuronal localization of pancreatic polypeptide (PP) and vasoactive intestinal polypeptide (VIP) immunoreactivity in the earthworm (Lumbricus terrestris). Brain Res. Bull. 2: 61-65.

Tatemoto, K. (1982a) Isolation and characterization of peptide $Y Y$ (PYY), a candidate gut hormone that inhibits pancreatic exocrine secretion. Proc. Natl. Acad. Sci. USA 79: 2514-2518.

Tatemoto, K. (1982b) Neuropeptide Y: Complete amino acid sequence of the brain peptide. Proc. Natl. Acad. Sci. USA 79: 54855489.

Tatemoto, K. (1989) Neuropeptide Y: Isolation, structure and function. In NPY, V. Mutt, K. Fuxe, T. Hökfelt, and J. M. Lundberg, eds., Raven, New York (in press).

Taylor, T. C., D. O. Thompson, K. E. Ebner, J. R. Kimmel, and A. B. Rawitch (1988) An immunochemical study of avian pancreatic polypeptide: The nature of the principal epitope. Mol. Immunol. 25: 961-973. 
Vallarino, M., J. M. Danger, A. Fasolo, G. Pelletier, S. Saint-Pierre, and $H$. Vaudry (1988) Distribution and charactcrization of neuropeptide $\mathrm{Y}$ in the brain of an elasmobranch fish. Brain Res. 448: 6776.

VanDongen, P. A. M., T. Hokfelt, S. Grillner, A. A. J. Verhofstad, H. W. M. Steinbusch, A. C. Cuello, and L. Terenius (1985) Immunohistochemical demonstration of some putative neurotransmitters in the lamprey spinal cord and spinal ganglia, 5-hydroxytryptaminetachykinin- and neuropeptide $\mathrm{Y}$-immunoreactive neurons and fibers. J. Comp. Neurol. 234: 501-522.
VanDongen, P. A. M., E. Theodorsson-Norheim, E. Brodin, T. Hökfelt, S. Grillner, A. Peters, A. C. Cuello, W. G. Forssman, M. Reinecke, E. A. Singer, and L. H. Lazarus (1986) Immunohistochemical and chromatographic studies of peptides with tachykinin-like immunoreactivity in the central nervous system of the lamprey. Peptides 7: 297-313.

Zamboni, L., and C. DeMartino (1967) Buffered picric acid formaldehyde: A new rapid fixative for electron microscopy. J. Cell Biol. 148A: 35 . 